\title{
Передумови становлення спіритизму та його вплив на активізацію британського “магічного відродження" в контексті наукової думки
}

Розглядається історія спіритуалізму, як частини наукової думки Вікторіанської Британії та його вплив на активізацію релігійно-культурного процесу “магічного відродження" в XIX ст.

Встановлено, що спіритизм, отримав велику популярність в Британії та фактично став альтернативною формою релігії. Визначено, що серед прихильників даних практик була значна кількість представників інтелектуальної спільноти, зокрема вчених, які намагались розкрити механізми спіритичних практик. Обгрунтовано, що на території Британії явище “магічного відродження” активізувало поширення містичних ідей та діяльність езотеричних товариств, які представляли собою альтернативні релігійні інститути. Встановлено відмінності окультних товариств від релігійних організацій: окультні товариства не мали такої жорсткої догматики як традиційні релігійні організації; багато їхніх адептів, зокрема вчених, належали до світської спільноти.

Ключові слова: історія, спіритизм, окультизм, наука, Британія, “магічне відродження”

Dmytro Pomazan

Prerequisites for the formation of Spiritualism and its impact on the activation of the British "Magical Revival" in the context of scientific thought

The history of Spiritualism as part of the scientific thought of Victorian Britain and its influence on the intensification of the religious and cultural process of the "Magical Revival" is revealed. The analyzed facts allow to establish a clear connection between the development of Spiritualism and the intensification of the occult movement in the context of the "Magical Revival" in Britain in the 19th century. This is quite significantly demonstrated in the interaction of occult organizations and scientists who have studied spiritual practices. Great importance is paid to the specifics of the Magical Revival. In addition, the relationship between occult doctrines and science is examined.

It is stated that Spiritism has been found to be very popular in Britain and has in fact become an alternative form of religion. It is determined that among the supporters of these practices was a significant number of representatives of the intellectual community, including scientists who tried to uncover the mechanisms of spiritual practices. It is substantiated that in Britain the phenomenon of "magical rebirth" intensified the spread of mystical ideas and the activities of esoteric societies, which were alternative religious institutions. The differences between occult societies and religious organizations were established: occult societies did not have such a rigid dogma as traditional forms of religion; many of their followers belonged to the secular community, including scholars. Spiritual practice, especially in the context of research, 
contributed to the popularization of mystical ideas, the implementation of which was possible in occult organizations. This factor is considered to be one of the key issues in intensifying the "Magical Revival" process in Britain.

Keywords: history, spiritualism, occultism, science, Britain, "Magical Revival"

Постановка проблеми. Процес “магічного відродження” вважається одним із найскладніших релігійно-суспільних феноменів на території Свропи у другій половині XIX ст. Під впливом саме цього процесу пройшла активізація містичних ідей та езотеричних організацій. Незважаючи на те, що даний феномен бере свій початок на території Франції XIX ст., одним 3 ключових його осередків була Британія, де активізація діяльності окультних товариств була наймасштабнішою. Втім, незважаючи на те, що “магічне відродження” (далі $\mathrm{MB})$ має велике значення для розуміння європейської історії, його вивчення є доволі фрагментарним, що своєю чергою не дозволяє цілісно розглянути історію даного явища. Тому, актуальність представленої теми зумовлена тим, що передумови Британського МВ у світлі спіритизму та наукової думки є недостатньо досліджені в сучасній історіографії західного езотеризму.

Аналіз останніх досліджень і публікацій. Більшість дослідників вивчає МВ як процес пов’язаний з релігійною парадигмою в контексті культурних перетворень. Наприклад, американська дослідниця Алекс Оуен у монографії "The Place of Enchantment British Occultism and the Culture of the Modern" опосередковано розглядає тему МВ у світлі культурної парадигми [10].

Водночас, змістовний аналіз МВ Британії в культурному контексті робить дослідниця Дженніфер Волтерс у роботі “Magical revival: occultism and the culture of regeneration in Britain 1880-1929” [11]. Авторка приділяє значну увагу становленню езотеричних доктрин через вплив соціокультурних передумов та огляду культурних витоків MB на території Британії у другій половині XIX ст.

Також доволі грунтовно розглядається історія становлення західної форми езотеризму в роботі британського історика Ніколаса Гудріка-Кларка “Тһе Western Esoteric Traditions A Historical Introduction" [4]. В даній монографії окультні товариства та містичні ідеї вивчаються в глобальній перспективі. Починаючи з епохи Стародавнього світу, автор послідовно висвітлює розвиток езотеричних ідей та їхні форми в різні хронологічні періоди. Через те, що MB на території Франції вважається одним з головних феноменів у історії окультних ідей та товариств, Н. Гудрік-Кларк акцентує на цьому питанні значну увагу [4, р. 192-196].

Схожою за змістом на книгу А. Оуена $є$ монографія канадської вченої Алісон Батлер "Victorian Occultism and the Making of Modern Magic", в якій авторка розглядає езотеричний рух Вікторіанської епохи [2]. На відміну від попередньої роботи А. Оуена, у дослідженні А. Батлера висвітлюється ширший спектр питань пов'язаних з історією езотеричних ідей. Втім, феномен MB також розглядається в іншому контексті. Фактично історія становлення 
окультного руху та МВ розкривається в контексті діяльності різноманітних езотеричних організацій, таких як Англійське товариство Розенкрейцерів або Золота Зоря [2, p. 1-3].

Традиційно МВ досліджують в контексті глобальніших процесів, таких як культурні або суспільні. Водночас спіритичний рух був однією з ключових світоглядних систем на теренах Британських островів. Його передумови та вплив на МВ $є$ маловивченим фрагментом історії. Окрім того, для ціліснішого розуміння даного явища, важливо розглядати спіритизм у світлі наукової думки. Зокрема, сучасна історіографія не дозволяє вичерпано відповісти на питання, які передумови сприяли розгортанню “магічногоо відродження" та яке місце в цьому процесі займає спіритизм.

Метою статті $є$ визначення факторів, які впливали, на становлення спіритизму, як частини Британського “магічного відродження" в контексті наукової думки.

Методологія дослідження базується на принципах історизму та наукової об'єктивності. Крім загальнонаукових методів: аналізу, синтезу, індукції та дедукції, у дослідженні використовувались спеціальні історичні методи: історико-порівняльний та історико-типологічний метод, а також, для комплексного дослідження використовувався міждисциплінарний метод симпатичного емпіризму для об'єктивного аналізу езотеризму, як релігійної складової суспільства.

Наукова новизна обраного питання полягає, насамперед, у формулюванні та розробці теми, як самостійної та цілісної дослідницької проблеми. Особливо це актуально в контексті того, що в сучасній історіографії немає вичерпаного погляду на фактори активізації “магічного відродження” в Британії.

\section{Виклад основного матеріалу дослідження}

Активізація процесу “магічного відродження" на території Британії у XIX ст. Стрімка популяризація езотеричних доктрин в Західноєвропейському регіоні бере свій початок у Франції XIX с. Розгортання даного процесу пов'язують з діяльністю видатного французького окультиста Луї Констана (Еліфаса Леві), котрий створив ряд езотеричних доктрин та практик, які викликали сильніший резонанс у суспільстві [5, р. 44; 2, p. 192-193]. Варто зазначити, що фоліанти Леві недоречно вважати абсолютно унікальними, фактично автор користувався окультними ідеями попередників, які мали розрізнений характер. Головною особливістю представлених робіт є те, що Еліфас Леві максимально ефективно об'єднав т. зв. традицію західного езотеризму в комплексну та структурну систему, в якій розглядається широкий спектр окультних питань. Доречно зауважити, що сучасні дослідники вважають роботи Еліфаса Леві каталізатором "магічного відродження" не тільки на території Франції, але i на Британських островах. Зокрема на це вказує те, що книги згаданого вище автора були перекладені та запроваджені англійськими окультистами одними 
3 найперших [5, p. 44-45], а наявність процесу МВ на території Британії підтверджує те той факт, що у другій половині XIX ст. саме там було відкрито 11 езотеричних організацій. Даний показник є найбільшим серед інших країн Західної Свропи [11, р. 8-9].

На наш погляд, для комплексного висвітлення питання доречно розглянути передумови та особливості “магічного відродження” саме на території Британії. Наведені вище факти чітко вказують, що розгортання цього процесу безсумнівно мало місце в британському суспільстві. А. Батлер звертає увагу, що популяризація окультних ідей проходила у різноманітних соціальних системах. До магічних практик вдавилися люди різних професій, рівня статків та освіти. Також варто зазначити, що в езотеричному наративі не було чіткої системності. Люди звертались до окультних методів різноманітної спрямованості, яка частіше всього була пов'язана з особистими проблемами [2, p. 1]. Однак далі буде продемонстровано, що спіритуалізм, як частина МВ має стійкі соціальні ознаки.

Одним з ключових аспектів становлення окультних рухів можна вважати процес інституалізації, що був притаманний як французькому, так і британському MB. Проте припускаємо, що британці мали серйозну перевагу в цьому питанні. На жаль у сучасній історіографії прийнято вважати, що ключовою подією в історії інституалізації містичних груп було створення ордену “Золота Зоря" у 1888 р. [2, p. 2; 10, p. 3-4]. Утім, ще задовго до появи Золотої Зорі, на території Британії діяло повноцінне окультне товариство під назвою “Англійське товариство Розенкрейцерів”. Ця організація розпочала свою діяльність у 1867 р., завдяки зусиллям видатного письменника Р. Літтла. Представлене товариство мало чіткі ознаки таємного езотеричного ордену. Наприклад, в лавах Англійського товариства Розенкрейцерів, активно вивчались та практикувались такі магічні напрями: алхімія, Кабала та християнський містицизм. Також дане товариство мало чітку ієрархічну структуру - дев’ять рівнів посвячення, що $є$ одним з ключових елементів окультних орденів. Формування чіткої структури, на засадах розенкрейцерської доктрини, зумовлено тим, що Р. Літтл отримав необхідні “таємні” документи з Німеччини, де ця організація успішно функціонувала ще у XVIII ст. [8, p. 179]. Наявність на території Британії окультного товариства дозволяє зробити висновок, що суспільство було готове до початку МВ навіть більше ніж французьке.

Проте, доречно зазначити, що в Британії існувала окультна традиція. Доволі яскраво цей феномен виражений в подальшому розгортанні МВ. Золота Зоря, про яку говорилося вище, була заснована діячами з Англійського товариства Розенкрейцерів. Зокрема, одним із засновників Золотої Зорі був розенкрейцер В. Весткотт, котрий заявляв, що теж має таємні документи, які дають йому право на заснування нових організацій. Окрім того, до Золотої Зорі долучився видатний розенкрейцер і активний діяч В. Вудман [4, р. 197-198]. Ці факти яскраво демонструють, що Англійське товариство Розенкрейцерів мало ваго- 
мий вплив на становлення як інших езотеричних організацій, так і конкретно Золотої Зорі.

Передумови становлення та розвитку спіритизму. Спіритична практика бере свій початок на території Північної Америки ХІХ ст. Даний регіон представляв собою динамічну соціальну систему, в якій релігійні протиріччя та загальна криза сакральних ідей стимулювали пошуки альтернативної форми релігї [6, p. 1075]. В цей період дві місцеві жительки Нью-Йорка-Маргарет та Кейтлін Фокс - заявили, що мають змогу спілкуватися зі “світом мертвих". Дана заява була зроблена після того, як в помешканні, де проживали сестри Фокс, були чутні дивні звуки, що мали системний характер. Саме ці звуки, на думку сестер, були повідомленнями мертвих людей, які намагались залишити інформацію. До такого висновку сестри Фокс прийшли після того, як в домі, де почались паранормальні звукові ефекти, знайшли останки людини. Цей факт підштовхнув сестер до встановлення зв'язку між звуками, які вони чули та рештками мертвого тіла. Представлена концепція отримала популярність серед значної кількості населення, котра мала доволі демократичну орієнтацію, що виражалось у популяризації даних ідей серед усіх верств населення.

Велика кількість людей, котрі цікавилась містичними явищами власноруч розпочали практики з даною концепцією, що сприяло іï розвитку та поширенню. Варто зазначити, що практика спіритизму реалізовувалась у вигляді певної гри, яка була схожа на театральні постанови. Фактично дані сеанси були виражені появою різних фізичних явищ, на кшталт пересування об'єктів інтер'єру, перегортання гральних карт або інших дрібних предметів, появою різноманітних звукових ефектів. Представлена релігійна модель задовольняла попит у альтернативній формі релігії, потреба в якій була дуже актуальна. На території Британії спіритизм з'явився у 1852 р. завдяки експериментам Марії Хайден і медіума Деніела Хома, котрі проводили масові спіритичні сеанси у вигляді вистав з фізичних явищ та ілюзіонізму [4, р. 187].

Вплив соціальних та релігійних чинників на активізацію британського “магічного відродження". Динамічна популяризація спіритизму на території Європейського регіону, зокрема в Британії, була зумовлено соціальними чинникам, які пов'язані з релігійною ситуацією та окультними товариствами. Ключовим суспільним процесом в цьому контексті була т. зв. індустріальна революція на території Британії, яка представляла собою швидке наростання промисловості. В наслідок цього процесу збільшилась кількість населення та зросла роль представників класу буржуазії (банкірів, юристів, торговців, вчителів, лікарів та представників дрібного бізнесу). Фактично Західна Європа та зокрема Британська імперія були місцем концентрації даного соціального прошарку. При аналізі статистичних даних можна стверджувати, що відсоток класу буржуазії в країнах Західної Свропи складав близько 25 \%, це вважається вагомим показником в порівнянні з іншими регіонами [9, р. 533-534]. 
На популяризацію спіритичних ідей впливало також і те, що британці на рівні сакральної моделі були готові прийняти такий містичний формат. Однією з ключових персон західного езотеризму є шведській містик Емануель Сведенборг, що жив у XVIII ст. В період з 1749 до 1771 pp. він створив низку богословських трактатів, які зробили його популярним у Європі $[8$, p. 211]. Незважаючи на те, що Е. Сведенборг був за національністю шведом, його ідеї отримали популярність на всій території Свропи, особливо на Британських островах. Зумовлено це тим, що в його рідній Швеції ортодоксальна релігія довгий час блокувала поширення містичних ідей, та не дозволяла створювати осередки в даному регіоні. Тому, доктрина Е. Сведенборга отримала найбільше визнання в ліберальній до езотеричних концепцій Англії. Вважається, що активне поширення доктрин Е. Сведенборга розпочалось після його смерті у 1772 р. Однак, як зазначає низка авторів, за кілька років до смерті містика його роботи були перекладені англійською мовою $[8$, p. 220]. Вплив ідей настільки великий, що у 1787 р. ряд англійців відмовляється від традиційної християнської віри, та за принципами шведського містика створює "Нову Церкву". Також, доволі показовим є той факт, що Нова Церква розповсюджується на більшості територій Британської імперії, навіть у таких віддалених домініонах, як Австралія [8, p. 221].

Важливим компонентом доктрини Е. Сведенборга є наявність життя після смерті та доволі автономне існування т. зв. духів. Наприклад, однією 3 центральних тем вчення містика можна вважати любовні стосунки між людьми, які вони транслюють у “потойбічний світ” після смерті. Шведський містик детально описував цей феномен у своїх роботах, зокрема, якщо людина вступила у союз з партнером, який ій не підходить, то після смерті їх розлучать, але у випадку коли люди “ідеально підходять” - вони залишаться разом після смерті та перетворяться у “єдиного ангела" [3, р. 84]. Фактично Е. Сведенборг був одним з перших, хто встановив зв'язок між матеріальним та потойбічним світом. Варто зазначити, що сучасники Е. Сведенборга сприйняли його концепцію у світлі спіритичних практик, які були притаманні періоду XIX ст. Такі видатні постаті XVIII ст. як Дж. Рід, Каліостро, У. Блейк заявляли, що змогли встановити зв'язок з мертвими та спілкувались з ними. Також у 1787 р. (задовго до сестер Фокс) на батьківщині містика діяв клуб, в якому люди намагались встановити контакт з мертвими [3, p. 85]. Наведені вище факти демонструють вагомий вплив містичних доктрин Е. Сведенборга, на становлення та популяризацію спіритуалістичного руху, особливо на теренах Британії, задовго до його появи в класичній формі.

Водночас, ще одним фактором, який впливав на розгортання спіритичного руху у Британії була релігійна криза конфесіональної парадигми. На відміну від сусідньої Франції, де в епоху Просвітництва почалась відкрита боротьба проти Церкви. На території Британських островів релігійна криза теж мала місце, але в більш латентній формі. Релігійні протиріччя Британії були закладені ще 
задовго до появи спіритизму або тенденцій епохи Просвітництва. Конфлікт інтересів існував в середині традиційних форм релігій та був виражений на конфесіональному рівні. Англіканська церква, яка була офіційним сакральним інститутом, довгий час займала домінуючі позиції в державі, але прихильники Католицької церкви теж вимагали для себе збільшення прав. Зокрема у 1829 р. католики отримали можливість на рівні з англіканцями приймати участь у виборчому процесі. Даний факт демонструє послаблення антикатолицької риторики та поглиблення релігійної кризи внаслідок протиріч між конфесіями [1, p. 228-229].

Розуміючи пряму загрозу для Англіканської церкви, як головної сакральної інституції держави, та можливість повторення історії з ортодоксальною Церквою у Франції під час Великої французької революції, ряд богословів та мислителів вирішили провести релігійну реформу. Цей процес в історіографії отримав назву “Оксфордський рух”, який бере свій початок у 1833 р. Лідером руху вважається Дж. Ньюман, один з головних авторів серії богословських трактатів “Шляхи часу”. Фактично метою Оксфордського руху було зближення Англіканської та Католицької церков. Метою такого зближення вважається відновлення традиційної форми релігії та зниження конфлікту між різними гілками християнства [1, р. 229].

Наведені вище факти яскраво демонструють наявність кризових процесів в середині релігійної системи. Водночас, крім спроб зупинення конфлікту на рівні церковної ієрархії, велика кількість людей шукала змогу реалізації своїх сакральних потреб в альтернативних формах релігійного досвіду. У ХІХ ст. спіритизм стає повноцінним релігійним напрямом, що задовольняє релігійні потреби значної кількості людей. Доречно зауважити, що серед спіритуалістів були не тільки містики або вільнодумці, але і велика кількість християн різноманітних конфесій. Така популярність спіритизму, зумовлена тим, що цей напрям не мав жорстких догм або обмежень, на противагу більшості традиційних релігій, а також дозволяв об'єднуватись людям з різноманітними світоглядними концепціями [10, р. 18-19].

Активізація наукових ідей як опосередкована передумова "магічного відродження". Втім, якщо послаблення релігійного впливу доречно вважати прямим фактором, через конкуренцію ідеологічних систем, то активізація наукових ідей варто вважати опосередкованою передумовою. Проте, цей фактор мав значний вплив на суспільство та його інститути у Вікторіанській Британії. Серед інтелектуальних моделей, що наповнювали культурний базис соціуму, варто виділити такі тенденції як романтизм, натуралізм та матеріалізм. Окрім того, приблизно з 1830-х рр. починається стрімке зростання популярності наукової думки. Фактично ідея використання наукового методу для пізнання будь-яких речей стає одним з головних інтелектуальних орієнтирів суспільства. Специфіка цього періоду полягала в тому, що науковці були переконані в універсальності науки та намагались використати академічний підхід для 
розуміння природи “духовних” явищ. Крім того, саме в Вікторіанський період виникає потреба у більш глибинному вивчені людини. Антропологічна орієнтація науки сприяє тому, що ідейні конструкти людини стають об'єктом дослідження. Езотеричні доктрини, як частина культурної парадигми Британського суспільства, почали активно цікавити наукову спільноту, бо ставали дедалі популярнішими [2, р. 162-163]. В цьому процесі спіритуалізм займав одну 3 ключових позицій, враховуючи його поширеність серед населення.

Беручи до уваги наведені вище передумови, можна стверджувати, що спіритизм став новою альтернативною формою релігії для значної кількості населення Британської імперії та інших країн Європи. Водночас, значна увага зі сторони інтелектуалів була прикута до цього феномену від його зародження в Західноєвропейському регіоні у 50-их рр. ХІХ ст. Варто зауважити, що певна кількість адептів, що займалась спіритичними сеансами були шахраями та використовували даний концепт з метою наживи. Втім, велика кількість практиків спіритизму насправді вірили у здатність спілкування з мертвими. Тому, переважна кількість спіритуалістів прагнули підтвердити експериментально здібності до “спілкування з мертвими”, розкрити механізм роботи цього явища. Також на даний процес впливало два фактори: перший - зростання інтересу до спіритуалізму в британському суспільстві, на це вказують статистичні дані, зокрема кількість спіритуалістичних об'єднань на території Британії (понад 200 організацій); другий - наявність серед спіритуалістів чималої кількості представників наукової спільноти, зокрема членів Королівського наукового товариства, яке вважалось флагманом європейської науки [2, p. 167].

Крім того, британські спіритуалісти відрізнялись від інших країн Європи прагненням до структуризації на рівні соціальної системи. Це демонструє той факт, що англійські спіритуалісти у другій половині XIX ст. створили "Національну федерацію спіритуалістів" та ряд інших організацій, зокрема “Асоціацію спіритуалістів”. Представлені структури були засновані для координованої глобальної взаємодії усіх британських спіритуалістів [6, p. 1080].

Враховуючи організованість та популярність представленого містичного напряму, наукова спільнота не могла ігнорувати це явище, зокрема у світлі евристичного дослідження спіритизму. Варто зазначити, що приблизно з середини XIX ст. наукова спільнота, що була представлена на території Британії, звертає увагу на спіритуалізм та розгортає експериментальні дослідження. Значна кількість дослідів пов'язаних зі спіритичними сеансами полягала у вивченні людської психіки. Пояснюється це тим, що більшість британських вчених розглядали ефекти спіритуалізму, як активацію у людей певних психічних процесів під час виконання спіритичних практик. Більшість дослідників жадали об'єктивного знання та розуміння механізму спіритичних методів. Одними 3 перших, хто почав фундаментальні наукові дослідження з цієї теми були такі видатні філософи та вчені: В. Крукс, О. Лодж, А. Уволес, Л. Рейлі, Ф. Майєрс, Ф. Подмор та ін. [4, р. 188]. 
Зростання уваги наукової спільноти до спіритизму розпочинається наприкінці XIX ст., після заснування в Лондоні у 1882 р. Товариства психічних досліджень. Керівником та засновником даного товариства був Генрі Сіджвік, популярний англійський філософ XIX ст. Активна позиція та прагнення Г. Сіджвіка до академічного вивчення спіритизму були підтримані значною кількістю вчених, особливо представниками з Кембриджського університету. Метою представленої організації було експериментальне дослідження спіритизму в контексті експериментального підходу. Членами організації були такі вчені: Б. Стюарт, Л. Керол, Е. Ленг, А. Бальфур, лорд Тенісон та ін. Склад організації та її активна діяльність - доволі вагомий показник, що вікторіанська наука дуже серйозно ставилася до окультної традиції, яка в даному випадку виступає у формі спіритуалізму [10, р. 33].

Також варто зазначити, що розвиток спіритизму сприяв пошукам нової сакральної парадигми та активізації окультних товариств, які починали свою діяльність під впливом ідей спіритуалізму. Доволі показовим є той факт, що засновники Англійського товариства Розенкрейцерів, яке згадувалося вище (У. Уескотт, С. Л. Макгрегор Мазерс, У. Вудман), активно практикували спіритизм та формували свої езотеричні концепції під його впливом [7, p. 26]. Проте найдужче спіритизм вплинув на становлення та розгортання діяльності Теософського товариства. Засновниця цього товариства - О. Блаватська у 1873 р. перебралася до Сполучених Штатів Америки. Приблизно у 1874 р. вона і Генрі Олкот проводять спіритичні сеанси, активно долучаються до діяльності спіритичних груп. О. Блаватська сприяла теоретичному та практичному поглибленню спіритичних концепцій за рахунок видання авторських матеріалів на цю тему. Доречно зауважити, що О. Блаватська розпочала спіритичні практики на території США, втім, використовуючи осередки Теософського товариства у Європі, зокрема в Британській імперії, вона змогла популяризувати їх на доволі велику аудиторію [4, p. 214-215].

Іншим показовим фактом впливу спіритичних ідей на діяльність окультних організацій $\epsilon$ історія найпопулярнішого окультного товариства XIX ст. - ордену “Золота Зоря”. Варто зазначити, що певні окультні товариств негативно ставилися до спіритизму через те, що даний напрям, на погляд адептів, був недостатньо змістовним у сакральному сенсі. Таку думку поділяли і представники ордену “Золота Зоря”, членам якого заборонялося проводити спіритичні сеанси. Та все ж, попри заборони, значна кількість членів ордену долучилася до нього саме за рахунок впливу спіритичних практик. Зокрема, видатні адепти Золотої Зорі, такі як В. Йєтс, У. Крукс, Ф. Кук та ін. активно використовували спіритуалістичні практики, навіть під час членства в ордені [7, p. 69-70].

Висновки. Враховуючі наведені вище факти можна зробити висновок, що спіритуалізм в контексті наукових досліджень активно впливав на розгортання $\mathrm{MB}$, як один з ключових компонентів. Було встановлено, що спіритизм набув значної популярності в Британії, та фактично став альтернативною формою 
релігії. Серед прихильників даних практик було чимало представників інтелектуальної спільноти, зокрема вчених, які намагались розкрити механізми спіритизму. На території Британії процес МВ сприяв поширенню містичних ідей та активізував діяльність езотеричних товариств. Згадані організації здебільшого формувались 3 людей, які були пов'язані зі спіритуалістичною діяльністю. Окультні товариства не мали такої жорсткої догматики як традиційні релігійні інституції, багато їхніх адептів належали до світської спільноти. Спіритична практика, особливо в контексті дослідницької діяльності, сприяла популяризації містичних ідей, реалізація яких була можлива в окультних організаціях. Цей фактор вважається одним з ключових у питанні активізації процесу МВ на території Британії.

1. Baryshnikov V. N., Borisenko V. N., Stetckevich M. S. The Oxford movement and the English reformation. Vestnik of Saint Petersburg University. History. 2017. Vol. 62. P. 826-838.

2. Butler A. Victorian Occultism and the Making of Modern Magic. London: Palgrave Macmillan, 2011.226 p.

3. Gibbons B. J. Spirituality and the Occult: From the Renaissance to the Modern Age. London: Psychology Press, 2001. 196 p.

4. Goodrick-Clarke N. The Western Esoteric Traditions. London: Oxford University Press, 2008. 286 p.

5. Granholm K. Dark enlightenment: The Historical, sociological, and discursive contexts of contemporary esoteric magic. Leiden: Brill, 2014. 243 p.

6. Hanegraaff W. Dictionary of Gnosis Western Esotericism. Leiden: Brill, 2006. 1231 p.

7. Howe E. The Magicians of the Golden Dawn: A Documentary History of a Magical Order, 1887-1923. York Beach: Samuel Weiser inc., 1984. 338 p.

8. Magee G. A. The Cambridge Handbook of Western Mysticism and Esotericism. London: Cambridge University Press, 2016. 514 p.

9. Merriman J. M. A history of modern Europe: from the Renaissance to the present. London: W. W. Norton, 2010. 1374 p.

10. Owen A. The Place of Enchantment British Occultism and the Culture of the Modern. Chicago: The University of Chicago Press, 2004. 356 p.

11. Walters J. Magical revival: occultism and the culture of regeneration in Britain c 18801929. 2007. URL: https://dspace.stir.ac.uk/bitstream/1893/3 23/1/Thesis.pdf.

\section{References}

1. Baryshnikov, V. N., Borisenko, M. S., Stetckevich M. S. (2017). The Oxford movement and the English reformation, Vestnik of Saint Petersburg University. History, vol. 62, p. 826-838. [in Rus.].

2. Butler, A. (2011). Victorian Occultism and the Making of Modern Magic, London, Palgrave Macmillan, 226 p. [in Eng.].

3. Gibbons, B. J. (2001). Spirituality and the Occult: From the Renaissance to the Modern Age, London, Psychology Press, 196 p. [in Eng.]. 
4. Goodrick-Clarke, N. (2008). The Western Esoteric Traditions, London, Oxford University Press, 286 p. [in Eng.].

5. Granholm, K. (2014). Dark enlightenment: The Historical, sociological, and discursive contexts of contemporary esoteric magic, Leiden, Brill, 243 p. [in Eng.].

6. Hanegraaff, W. (2006). Dictionary of Gnosis Western Esotericism, Leiden, Brill, 1231 p. [in Eng.].

7. Howe, E. (1984). The Magicians of the Golden Dawn: A Documentary History of a Magical Order, 1887-1923, York Beach, Samuel Weiser inc, 338 p. [in Eng.].

8. Magee, G. A. (2016). The Cambridge Handbook of Western Mysticism and Esotericism, London, Cambridge University Press, 514 p. [in Eng.].

9. Merriman, J. M. (2010). A history of modern Europe: from the Renaissance to the present, London, W. W. Norton, 1374 p. [in Eng.].

10. Owen, A. (2004). The Place of Enchantment British Occultism and the Culture of the Modern, Chicago, The University of Chicago Press, 356 p. [in Eng.].

11. Walters, J. (2007). Magical revival: occultism and the culture of regeneration in Britain c 1880-1929. Retrieved from https://dspace.stir.ac.uk/bitstream/1893/3 23/1/Thesis pdf. [in Eng.]. 